\title{
Metode Perawatan Kesehatan Mental Dalam Islam
}

\author{
Ratnawati \\ Institut Agama Islam Negeri (IAIN) Curup \\ ratnawati12@gmail.com
}

\begin{abstract}
This research departs from the problem regarding most people in mental health care businesses who prefer shamanism practices which are generally black magic which is not at all relevant to Islamic teachings. On the other hand that Islam as a religion, contains teachings and complete instructions, including methods of mental health care. This is the main focus of this research, how is the Method of Care for Mental Health in Islam. The purpose of this study was to find concrete and valid data about mental health care in Islam, both in the form of verses of the Qur'an, Hadith or opinions of the scholars, especially those relating to the meaning of mental health and methods of maintaining mental health. The method used in this study is descriptive qualitative with the Religion psychology approach, which is where the psychology of religion functions as a formal object in this study while the verses of the Koran, Hadith and the opinions of the scholars are relevant to the subject matter in the study, is a material object. From all the topics related to the main problem of this research, found that, the relationship between religion and mental health in Islam is a therapy, which lies in the attitude of total surrender to Allah SWT, with complete surrender the peace of mind will be found, which can later be forming a balanced human life in the afterlife. Healthy mental criteria, in Islam are grouped into six categories, namely: Having a positive mental attitude towards himself. Selfactualization. Able to hold integration with existing psychological functions. Able to be autonomous towards yourself (Mandiri). Have an objective perception of the reality that exists. Able to harmonize environmental conditions with yourself. And the last method, that the model of mental health care in Islam is; methods of faith, Islam, and ihsan.
\end{abstract}

Keywords: Islam, Mental, Healthy, Care.

\section{Abstrak}


Penelitian ini berangkat dari permasalahan perihal kebanyakan masyarakat dalam usaha perawatan kesehatan mental lebih memilih praktek perdukunan yang pada umumnya bersifat black magic yang sama sekali tidak relevan dengan ajaran Islam. Di sisi lain bahwa Islam sebagai agama, mengandung ajaran dan petunjuk yang lengkap, termasuk metode perawatan kesehatan mental. Inilah yang menjadi fokus utama penelitian ini, bagaimana Metode Perawatan Keshatan Mental dalam Islam. Tujuan Penelitian ini adalah untuk menemukan data-data yang konkrit dan valid tentang perawatan kesehatan mental dalam Islam, baik berupa ayat-ayat al-Qur'an, Hadis atau pendapat para ulama, terutama yang berkaitan dengan makna kesehatan mental dan metode pemeliharaan kesehatan mental. Metode yang digunakan dalam penelitian ini adalah deskriptif kualitatif dengan pendekatan psikhologi Agama, yaitu di mana ilmu psikologi agama befungsi sebagai objek formal dalam penelitian ini sedangkan ayat-ayat al-Qur'an, Hadis dan pendapat para ulama yang relevan dengan judul bahasan dalam penelitian, adalah sebagai objek material. Dari seluruh bahasan yang bekaitan dengan permasalahan utama penelitian ini, menemukan bahwa, adanya hubungan agama dengan kesehatan mental dalam Islam adalah sebagai terapi, yaitu terletak pada sikap penyerahan diri seutuhnya kepada Allah SWT, dengan penyerahan sepenuhnya maka ketenangan jiwa akan di dapati, yang nantinya dapat membentuk hidup manusia jadi seimbang dunia akhirat. Kriteria mental yang sehat, dalam Islam dikelompokkan ke dalam enam kategori, yaitu: Memiliki sikap batin yang positif terhadap dirinya sendiri. Aktualisasi diri. Mampu mengadakan integrasi dengan fungsi-fungsi psikis yang ada. Mampu berotonom terhadap diri sendiri (Mandiri). Memiliki persepsi yang obyektif terhadap realitas yang ada. Mampu menselaraskan kondisi lingkungan dengan diri sendiri. Dan metode terakhir, bahwa model perawatan kesehatan mental dalam Islam adalah; metode iman, islam, dan ihsan.

Kata Kunci : Islam, Mental, Sehat, Perawatan.

\section{Pendahuluan}

Kehidupan modern dewasa ini telah tampil dalam dua wajah yang antagonistik. Di satu sisi modernisme telah berhasil mewujudkan kemajuan yang spektakuler, khususnya dalam bidang ilmu pengetahuan dan teknologi. Di sisi lain, ia telah menampilkan wajah kemanusiaan yang buram berupa kemanusiaan modern sebagai kesengsaraan rohaniah. Modernitas telah menyeret manusia pada kegersangan spiritual. Ekses ini merupakan konsekuensi logis dari paradigma modernisme yang terlalu bersifat materialistik dan mekanistik, dan 
unsur nilai-nilai normatif yang telah terabaikan. Hingga melahirkan problemproblem kejiwaan yang variatif.

Ironisnya, masalah kejiwaan yang dihadapi individu sering mendapat reaksi negatif dari orang-orang yang berada di sekitarnya. Secara singkat lahirnya stigma ditimbulkan oleh keterbatasan pemahaman masyarakat mengenai etiologi gangguan jiwa, di samping karena nilai-nilai tradisi dan budaya yang masih kuat berakar, sehingga gangguan jiwa sering kali dikaitkan oleh kepercayaan masyarakat yang bersangkutan. Oleh karenanya, masih ada sebagian masyarakat yang tidak mau terbuka dengan penjelasan-penjelasan yang lebih ilmiah (rasional dan obyektif) dan memilih untuk mengenyampingkan perawatan medis dan psikiatris terhadap gangguan jiwa.

Semua orang yang ada di dunia ini pasti ingin untuk hidup sehat, karena kesehatan adalah harta yang tak ternilai harganya, banyak cara yang di tempuh oleh semua orang untuk memperoleh kesehatan. Seseorang dikatakan sehat tidak hanya dilihat dari segi fisiknya saja, tetapi juga harus ditinjau dari segi kesehatan mentalnya. Mental merupakan salah satu unsur pembentuk jiwa. Kesehatan mental sangat penting untuk selalu dijaga, karena fisik yang kuat tak akan berarti tanpa mental jiwa yang sehat. Tidak seorangpun yang tidak ingin menikmati ketenangan hidup, dan semua orang akan berusaha mencarinya, meskipun tidak semuanya dapat mencapai yang diinginkannya itu. Bermacam sebab dan rintangan yang mungkin terjadi sehingga banyak orang yang mengalami kegelisahan, kecemasan dan ketidak puasan.

Hidup yang bermakna menjadi sebuah jawaban, maka dari situlah kepribadian Islam menjadi harapan di tengah-tengah kemajemukan masyarakat dan peradaban global. Sebagai alternatif, kesehatan mental merupakan solusi melalui paradigma pendidikan untuk mengembangkan sisi-sisi potensi kecerdasan qalbiyah baik secara spiritual, kognitif-intelektual, afeksi-emosional dan psikomotor-amaliah. Upaya pemetaaan konsep pendekatan dalam tulisan ini tidak lepas dari paradigma psikologi Islam sebagai "pisau analisis" dalam memahami fenomena psikologis manusia dan kemanusiaanya secara utuh dalam seluruh struktur kepribadiannya. Dengan demikian, dalam tulisan ini persoalan yang akan dikaji tidak lebih merupakan bahan telaah Dalam literatur Psikologi, ditemukan beberapa pengertian kesehatan mental. Musthafa Fahmi, sebagaimana dikutip oleh Muhammad Mahmud menemukan dua pola dalam mendefinisikan kesehatan mental: Pertama, pola negatif (salabiy), bahwa kesehatan mental adalah terhindarnya seseorang dari segala neurosis (al-amradh al-ashabiyah) dan psikosis (al-amradh al-drihaniyah). Kedua, pola positif (ijabiy), bahwa kesehatan mental adalah kemampuan individu dalam penyesuaian diri sendiri dan terhadap lingkungan sosialnya. ${ }^{1}$

${ }^{1}$ Muhammad Mahmud, 'Ilm al-Nafs al-Ma'ashir fi Dhaw I al-Islam, (Jeddah: Dar al-Syuruq, 1984), h. 227 
Kesehatan mental adalah terhindarnya seseorang dari keluhan dan gangguan mental baik berupa neurosis maupun psikosis (penyesuaian diri terhadap lingkungan sosial). ${ }^{2}$ Zakiah Daradjat secara lengkap mendefinisikan kesehatan mental dengan terwujudnya keserasian yang sungguh-sungguh antara fungsi-fungsi kejiwaan dan terciptanya penyesuaian diri antara individu dengan dirinya sendiri dan lingkungannya berdasarkan keimanan dan ketakwaan. ${ }^{3}$ Dalam pengertian yang luas kesehatan mental dapat diartikan sebagai terwujudnya keserasian yang sungguh-sungguh antara fungsi-fungsi kejiwaan dan terciptanya penyesuaian diri antara manusia dengan dirinya sendiri dan lingkungannya, berlandaskan keimanan serta bertujuan untuk mencapai hidup yang bermakna dan bahagia di dunia dan di akhirat.

Dari beberapa definisi kesehatan mental tersebut maka dapat dipahami bahwa definisi kesehatan mental adalah terwujudnya keserasian yang sungguhsungguh antara fungsi-fungsi kejiwaan dan terciptanya penyesuaian diri antara manusia dengan dirinya sendiri dan lingkungannya, berlandaskan keimanan dan ketakwaan, serta bertujuan untuk mencapai hidup yang bermakna yaitu bahagia di dunia dan di akhirat.

Dengan demikian fungsi-fungsi jiwa seperti pikiran, perasaan, sikap jiwa, pandangan dan keyakinan hidup harus dapat saling membantu dan bekerja sama satu dengan lainnya sehingga dapat tercapai keharmonisan yang dapat menjauhkan orang dari perasaan ragu dan bimbang serta terhindar dari kegelisahan dan pertentangan batin.

Islam memiliki konsep tersendiri dan khas tentang kesehatan mental. Pandangan Islam tentang kesehatan jiwa berdasarkan atas prinsip keagamaan dan pemikiran falsafat yang terdapat dalam ajaran-ajaran Islam. Dapat ditegaskan bahwa iman dan takwa memiliki relevansi yang sangat erat sekali dengan soal kejiwaan. Iman dan takwa itulah arti psikologi dan kesehatan mental yang sesungguhnya bagi manusia dalam Islam. Hanya Allah, akan memberikan hati mereka rasa aman, tenang dan tentram sehingga mereka dapat beraktivitas dengan maksimal sehingga mencapai hasil yang diinginkan.

\section{Hasil dan Pembahasan}

\section{Agama Islam dan Kesehatan Mental}

Agama tampaknya memang tidak dapat dipisahkan dari kehidupan manusia. Pengingkaran manusia terhadap agama mungkin karena faktor-faktor tertentu baik yang disebabkan oleh kepribadian maupun lingkungan masing-

\footnotetext{
${ }^{2}$ Yusak Burhanuddin. Kesehatan Mental, (Bandung: Pustaka Setia, 1998), h. 21

${ }^{3}$ Zakiah Daradjat, Kesehatan Mental, (Jakarta: LP IAIN, 1985), h. 76
} 
masing. Namun untuk menutupi atau meniadakan sama sekali dorongan dan rasa keagamaan kelihatannya sulit dilakukan, hal ini Karena manusia ternyata memiliki unsur batin yang cenderung mendorongnya untuk tunduk kepada Zat yang gaib, ketundukan ini merupakan bagian dari faktor intern manusia dalam psikologi kepribadian dinamakan pribadi (Self) ataupun hati nurani (conscience of man). ${ }^{4}$

Fitrah manusia sebagai makhluk ciptaan Allah SWT ialah manusia diciptakan mempunyai naluri beragama yaitu agama tauhid. Kalau ada manusia tidak beragama tauhid, maka tidak wajar, mereka tidak beragama tauhid itu hanya karena pengaruh lingkungan, seperti yang ada dalam (QS Ar Ruum 30:30)

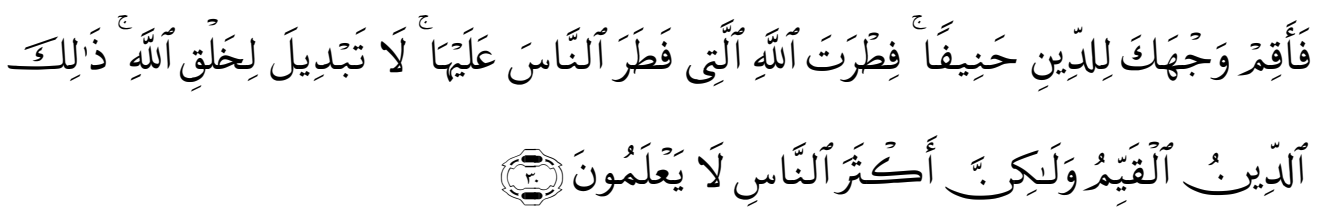

Maka hadapkanlah wajabmu dengan Lurus kepada agama Allab; (tetaplah atas) fitrah Allah yang telab menciptakan manusia menurut fitrah itu. tidak ada peubahan pada fitrab Allah. (Itulab) agama yang lurus; tetapi kebanyakan manusia tidak mengetabui. (QS Ar Ruum 30)

Manusia diciptakan Allah mempunyai naluri beragama yaitu agama tauhid. kalau ada manusia tidak beragama tauhid, Maka hal itu tidaklah wajar. mereka tidak beragama tauhid itu hanyalah lantara pengaruh lingkungan.

\section{Agama sebagai Terapi Kesehatan Mental}

Terapi merupakan usaha penanggulangan suatu penyakit atau gejalah yang ada dalam diri makhluk hidup. Usaha penanggulangan gangguan kesehatan rohani atau mental sebenarnya dapat dilakukan sejak dini oleh yang bersangkutan. Dengan mencari cara yang tepat untuk menyesuaikan diri dengan memilih norma-norma moral, maka gangguan mental akan terselesaikan. Dalam konteks ini terlihat hubungan agama sebagai terapi kekusutan mental. Sebab, nilai-nilai luhur termuat dalam ajaran agama bagaimanapun dapat digunakan untuk penyesuaian dan pengendalian diri, hingga terhindar dari konflik batin.

Pendekatan terapi keagamaan ini dapat dirujuk dari informasi al-Qur'an sendiri sebagai kitab suci. Sebagaimana pernyataan Allah dalam Q.S. Yunus : 57

4 Abdul Mujib \& Mudzakir, Jusuf, Nuansa-Nuansa Psikologi Islam, (Jakarta: PT Raja Grafind Persada, 2001), h. 99 


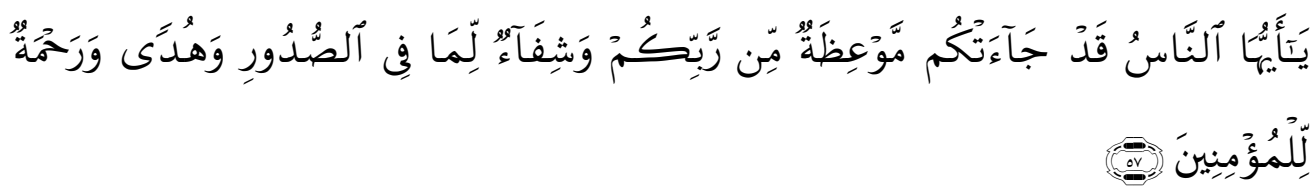

'Wahai manusia, sesunggubnya telah datang dari Tubanmu Al-Qur'an yang mengandung pelajaran, penawar bagi penyakit batin (jiwa), tuntunan serta rabmat bagi orang-orang yang beriman.

Dan Q.S. Al Isra' : 82.

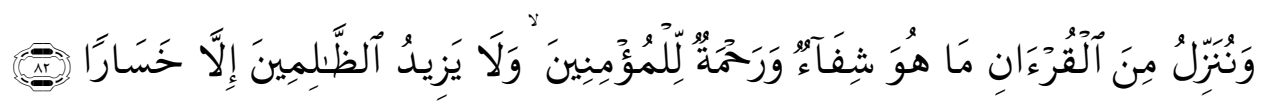

Dan Kami turunkan dari Al Quran suatu yang menjadi penawar dan rabmat bagi orangorang yang beriman dan Al Quran itu tidaklah menambah kepada orang-orang yang zalim selain kerugian.” (Q.S Isra' : 82)

Dalam Al-Qur'an juga dijelaskan bahwa Allah dengan tegas menerangkan bahwa ketenangan jiwa dapat dicapai dengan dzikir (mengingat Allah), rasa takwa dan perbuatan baik adalah metode pencegahan dari rasa takut dan sedih, jalan bagaimana cara seseorang mengatasi kesukaran ialah dengan kesabaran dan shalat, dan Allah mensifati diri-Nya bahwa Dia-lah Tuhan Yang Maha Mengetahui dan Bijaksana yang dapat memberikan ketenangan jiwa ke dalam hati orang yang beriman. ${ }^{5}$

Jadi, semakin dekat seseorang kepada Tuhan, dan semakin banyak ibadahnya, maka akan semakin tentramlah jiwanya serta semakin mampu ia menghadapi kekecewaan dan kesukaran-kesukaran dalam hidup. Dan demikian pula sebaliknya, semakin jauh orang itu dari agama, akan semakin susahlah baginya untuk mencari ketentraman batin. ${ }^{6}$ Ini menunjukkan bahwa agama terkait dengan ini pendekatan diri kepeda Tuhan merupakan terapi yang tepat dalam menanggulangi masalah masalah kehidupan termasuk di dalamnya hal-hal yang menyebabkan gangguan pada kesehatan mental.

Agama sebagai terapi kesehatan mental dalam Islam sudah ditunjukkan secara jelas dalam ayat-ayat Al-Quran, di antaranya

a. Ayat-ayat yang membahas tentang ketenangan: 1984), h. 279

${ }^{5}$ Muhammad Mahmud, 'Ilm al-Nafs al-Ma'ashir fi Dhaw 'I al-Islam, (Jeddah: Dar al-Syuruq, 
(QS An Nahl 16:97):

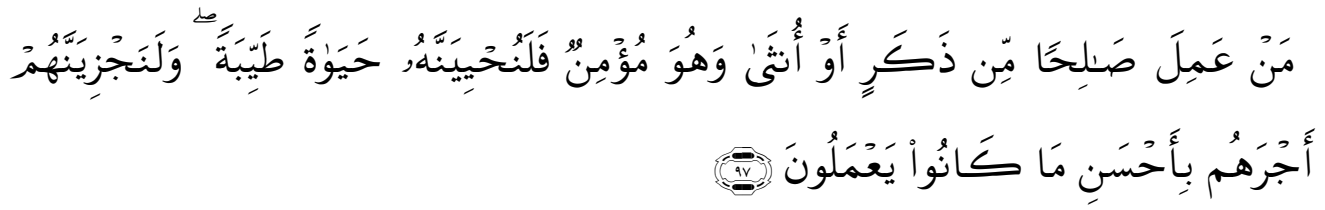

"Barang siapa yang mengerjakan amal saleh, baik laki-laki maupun perempuan dalam keadaan beriman, Maka Sesunggubnya akan kami berikan kepadanya kehidupan yang baik dan Sesunggubnya akan kami beri balasan kepada mereka dengan pahala yang lebih baik dari apa yang Telah mereka kerjakan

(QS Ali Imran : 104):

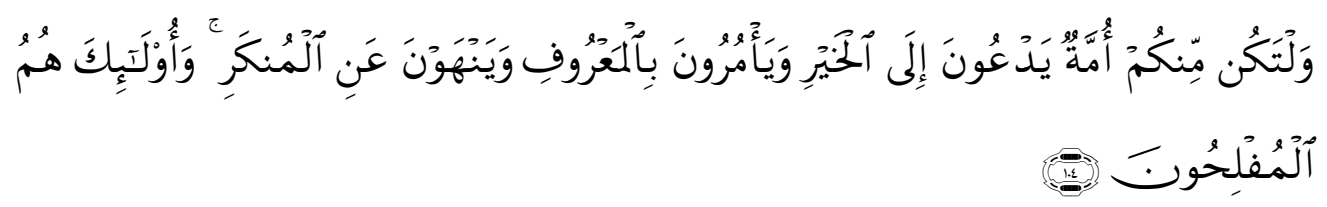

Dan hendaklah ada di antara kamu segolongan umat yang menyeru kepada kebajikan, menyurub kepada yang ma'ruf dan mencegah dari yang munkar.

(QS Al-Qashash:77):

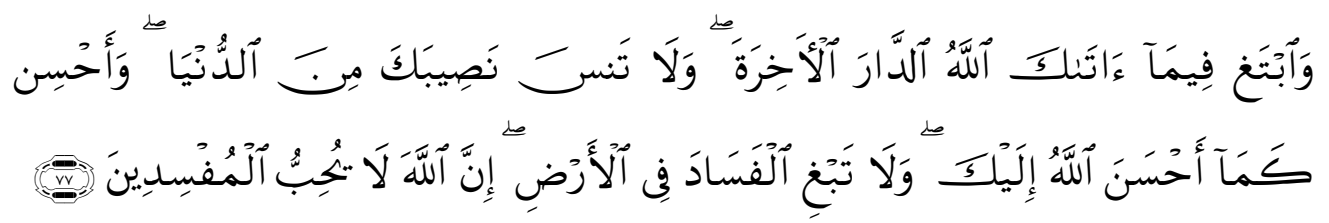

Dan carilah pada apa yang telah dianugerabkan Allah kepadamu (kebahagiaan) negeri akbirat, dan janganlah kamu melupakan bahagianmu dari (kenikmatan) duniawi dan berbuat baiklah (kepada orang lain) sebagaimana Allah telah berbuat baik, kepadamu, dan janganlah kamu berbuat kerusakan di (muka) bumi. Sesunggubnya Allah tidak menyukai orang-orang yang berbuat kerusakan.

b. Ayat -ayat yang membahas tentang kebahagiaan adalah:

(QS Al-'Araf: 35):

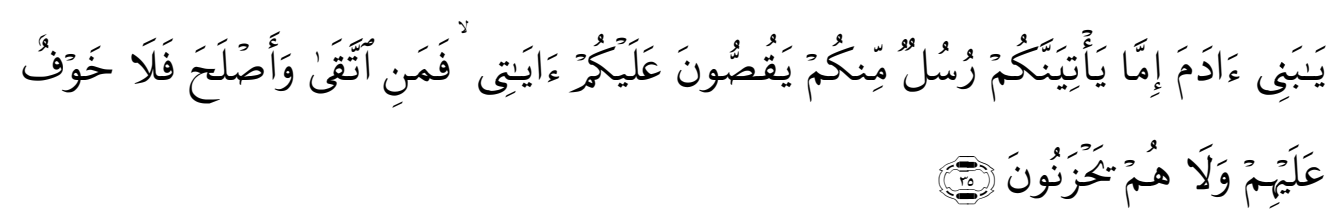

Hai anak-anake Adam, jikea datang kepadamu Rasul-rasul daripada kamu yang menceritakan kepadamu ayat-ayat-Ku, Maka Barangsiapa yang bertakwa dan Mengadakan perbaikan, tidaklah ada kekhawatiran terhadap mereka dan tidak (pula) mereka bersedih bati 
(QS Al- Ra'd : 28):

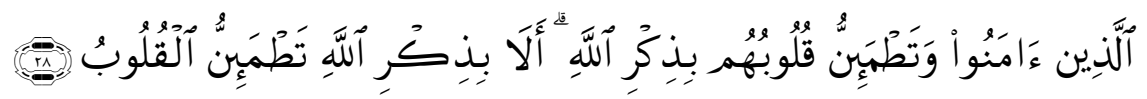

(yaitu) orang-orang yang beriman dan hati mereka manjadi tenteram dengan mengingat Allah. Ingatlah, hanya dengan mengingati Allah-lah hati menjadi tenteram.

(QS Al- Baqarah:15):

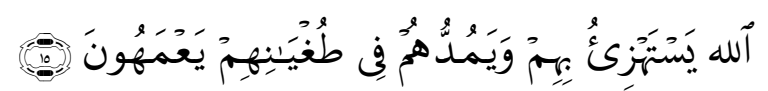

Allah akan (membalas) olok-olokan mereka dan membiarkan mereka terombang-ambing dalam kesesatan mereka.

\section{Kesehatan Mental: Solusi Pengembangan Kecerdasan Qalbiah}

Apabila hamba Allah telah berhasil melakukan pendidikan dan pelatihan penyehatan, pengembangan dan pemberdayaan jiwa (mental), seperti yang ditulis M. Hamdani Bakran Adz-Dzaky (dalam Yusah Burhanuddin) maka ia akan dapat mencapai tingkat kejiwaan atau mental yang sempurna, yaitu akan tersingkap ${ }^{7}$ :

Pertama, Kesempurnaan Jiwa, yaitu integritasnya jiwa muthmainnah (yang tentram), jiwa radhiyah (jiwa yang meridhai), dan jiwa yang mardhiyah (yang diridhai) sehingga memiliki stabilitas emosional yang tinggi dan tidak mudah mengalami stress, depresi dan frustasi. Jiwa ini selalu akan mengajak pada fitrah Ilahiyah Tuhannya. Indikasi hadirnya jiwa ini akan terlihat pada prilaku, sikap dan gerak-geriknya yang tenang, tidak tergesa-gesa, penuh pertimbangan dan perhitungan yang matang, tepat dan benar, tidak terburu-buru untuk bersikap apriori dan berprasangka negatif. ${ }^{8}$ Jiwa radhiyah akan mendorong diri bersikap lapang dada, tawakkal, tulus ikhlas dan sabar dalm mengaplikasikan perintah Allah dan menjauhi seluruh larangan-Nya dan meneima dengan lapang dada segala ujian dan cobaan yang datang dalam hidup dan kehidupannya, dalam artian hampir-hampir tidak pernah mengeluh, merasa susah, sedih dan takut menjalani kehidupan ini (lihat QS. Yunus: 62-64). Sedangkan jiwa mardhiyah adalah jiwa yang telah memperoleh title dan gelar kehormatan dari Allah swt. Sehingga keimanan, keislaman,dan keihsanannya tidak akan pernah mengalami erosi, dekadensi dan distorsi. ${ }^{9}$ Dalam hal ini diberikan otoritas penuh kepada jiwa untuk berbuat, berkarya dan beribadah di dalam ruang dan waktu Tuhannnya yang terlepas dari jangkauan makhluk. (periksa QS. Al-Fajr: 27-30).

\footnotetext{
${ }^{7}$ Yusak Burhanuddin, Kesehatan Mental, (Bandung: Pustaka Setia, 1998), h. 81

${ }^{8}$ Hanna Djumhana Bustaman, Integrasi Psikologi dengan Islam, (Yogyakarta: Pustaka Pelajar, 2001). h. 87

${ }^{9}$ Jalaluddin, Psikologi Agama, (Jakarta: PT Raja Grafindo Persada, 2010), h. 63
} 
Kedua, Kecerdasan Uluhiyah, yaitu kemampuan fitrah seseorang hamba yang shalih untuk melakukan interaksi vertikal dengan Tuhannya; kemampuan mentaati segala apa yang telah diperintahkan dan menjauhi diri dari apa yang dilarang dan dimurkai-Nya serta tabah terhadap ujian dan cobaan-Nya. Sehingga dengan kecerdasan ini akan terhindar dari sikap menyekutukan Allah (syirik), sikap menganggap remeh hukum-hukum-Nya atau sikap menundanunda diri untuk melakukan kebaikan dan kebenaran (fasiq), sikap suka melanggar hukum Allah (zhalim), sikap mendua dihadapan-Nya (nifaq), dan sikap suka mengingkari atau mendustakan ayat-ayat-Nya (kufur). ${ }^{10}$ Kedekatan Allah akan membuat hamba-Nya menyaksikan kebesaran dan kesucian-Nya (ihsan) dengan interaksi vertikal yang bersifat transendental, empirik dan hidup, bukan spekulasi dan ilusi. Firman Allah: "Dan apabila hamba-hamba-Ku bertanya kepadamu tentang Aku, maka sesungguhnya Aku adalah dekat" (QS. Al-Baqarah: 186), "Dan Kami lebih dekat kepada manusia daripada urat lehernya" (QS.Qaaf:16). Jadi, kecerdasan uluhiyah adalah kesempurnaan fitrah yang dimiliki oleh seorang hamba yang shalih, sehingga dapat merasakan kehadiran Allah dalam setiap aktifitasnya, merasakan bekasan-bekasan pengingkaran, kedurhakaan dan dosa, dan mampu mengalami mukasyafah akal fikiran, qalb dan inderawi.

Ketiga, Kecerdasan Rububiyah, yaitu kemampuan fithrah seorang hamba yang shalih dalam hal: memelihara dan menjaga diri dari hal-hal yang dapat menghancurkan kehidupanya (QS. At-Taubah:112); mendidik diri agar menjadi hamba yang pandai menemukan hakekat citra diri dengan kekuatan ilmu (QS. Al-Kahfi:65); membimbing diri secara totalitas patuh dan tunduk kepada Allah serta dapat memberikan kerahmatan pada diri dan lingkungannya ("Wahai orang-orang yang beriman, peliharalah dirimu dan keluargamu dari api neraka..."(QS. At-Tahrim: 6); menyembuhkan dan menyucikan diri dari penyakit dan gangguan yang dapat melemahkan bahkan menghancurkan potensi jiwa, akal fikiran, qalbu dan inderawi di dalam menangkap dan memahami kebenaran-kebenaran hakiki dengan melakukan pertaubatan dan perbaikan diri seutuhnya (An-Nisa':108). Dengan demikian indikasi seseorang yang telah memperoleh kecerdasan rububiyah biasanya ia memiliki kekuatan, kewibawaan dan otoritas yang sangat kuat dalam hal menanamkan nilai-nilai kebaikan dan kebenaran, mempengaruhi dan mengajak untuk melakukan perbaikan dan perubahan yang positif pada prilakum sikap dan penampilan yang tulus dan lapang dada tanpa adanya paksaan dan tekanan baik kepada dirinya atau orang lain dan lingkungannya; memberikan penyembuhan terhadap penyakit, baik penyakit yang bersifat psikologis, spiritual, moral ataupun fisik; dan memberikan

10 Hanna Djumhana Bustaman, Integrasi Psikologi dengan Islam, (Yogyakarta: Pustaka Pelajar, 2001), h. 92 
perawatan terhadap kualitas keimanan, keislaman, keihsanan baik terhadap diri maupun lingkungan sekitarnya.

Keempat, Kecerdasan Ubudiyah, yitu kemampuan fitrah seseorang yang shalih dalam mengaplikasikan ibadah dengan tulus tanpa merasa terpaksa dan dipaksa, akan tetapi menjadikan ibadah sebagai kebutuhan yang sangat primer dam merupakan makanan bagi ruhani dan jiwanya. ${ }^{11}$ Firman Allah "Kami telah menjadikan mereka itu sebagai pemimpin-pemimpin yang memberikan petunjuk dengan perintah Kami dan telah Kami wahyukan kepada mereka mengerjakan kebajikan, mendirikan shalat, menunaikan zakat, dan hanya kepada Kamilah mereka selalu menyembah" (Al-Ambiyaa':73). Jadi kecerdasan ubudiyah suatu anugerah dari Allah swt berupa kemampuan dan skill mengaplikasikan sikap penghambaan sangat tulus dan otomatis, baik dalam keadaan sendiri maupun jamaah, baik secara terang-terangan atau sembunyisembunyi, baik secara vertikal atau horisontal, baik dalam kondisi bagaimanapun, dimanapun dan kapanpun.

Kelima, Kecerdasan Khuluqiyah, ialah kemampuan fitrah seseorang yang shalih dalam berperilaku, bersikap dan berpenampilan terpuji. Dalam hal ini terintegrasi dalam akhlak yang baik. Suatu perbuatan atau prilaku dapat dikatakan sebagai akhlak apabila memenuhi dua syarat, yaitu :

a. Perbuatan dilakukan dengan berulang-ulang. Apabila perbuatan hanya dilakukan sesekali saja, maka perbuatan itu tidak dapat dikatakan sebagai akhlak.

b. Perbuatan timbul dengan mudah tanpa dipikirkan atau diteliti lebih dalam sehingga ia benar-benar merupakan suatu kebiasaan. Jika perbuatan itu timbul karena terpaksa atau setelah dipikirkan atau dipertimbangkan secara matang, tidaklah disebut akhlak. Karena akhlak Islamiyah mempunyai ciri yaitu kebaikannya bersifat mutlak (al-khairiyah al-muthlaqah), kebaikannya bersifat menyeluruh (as-salahiyyah al-'ammah), tetap, langgeng dan mantap, kewajiban yang harus dipatuhi (al-ilzam al-mustajab), dan pengawasan yang menyeluruh (ar-raqabah al-muhithah). Firman Allah "Sesungguhnya kamu benar-benar memiliki akhlak (budi pekerti) yang agung" (QS. Al-Qalam: 4), Hadits Nabi "Sesungguhnya aku telah diutus untuk menyempurnakan akhlak yang mulia" (HR. Ahmad dari Abu Hurairah).

Dengan demikian, atas tersingkapnya karakter lima kecerdasan sebagaimana disebutkan di atas, merupakan pengejawantahan dari wujud kesehatan mental sebagai solusi pengembangan qalbiah itu sendiri. Adapun bentuknya terefleksikan dari struktur kepribadian. Jika struktur dalam kendali kalbu, maka komponen nafsani manusia memiliki potensi positif, yang apabila

11 Hanna Djumhana Bustaman, Integrasi Psikologi dengan Islam, (Yogyakarta: Pustaka Pelajar, 2001), h. 83 
dikembangkan secara maksimal akan mendatangkan kecerdasan yang teraktualisasikan sebagai kecerdasan qalbiyah yang meliputi: kecerdasan intelektual, kecerdasan emosional, kecerdasan moral, kecerdasan spiritual, dan kecerdasan beragama. Dari sini insya Allah potensi manusia dalam aktualisasnya sebagai khalifah fil ardy akan mewujudkan sosok insan kamil yang membawa misi rahmatan lil 'alamin.

\section{Tanda-tanda kesehatan mental dalam Islam}

Ada bebeapa tanda mental yang sehat dalam Islam, anataa lain ${ }^{12}$ :

a. Terhindar dari Gangguan Jiwa

Zakiyah Daradjat mengemukakan perbedaan antara gangguan jiwa (neurose) dengan penyakit jiwa (psikose), yaitu:

1) Neurose masih mengetahui dan merasakan kesukarannya, sebaliknya yang kena psikose tidak.

2) Neurose kepribadiannya tidak jauh dari realitas dan masih hidup dalam alam kenyataan pada umumnya. sedangkan yang kena psikose kepribadiaannya dari segala segi (tanggapan, perasaan/emosi, dan dorongan-dorongan) sangat terganggu, tidak ada integritas, dan ia hidup jauh dari alam kenyataan. ${ }^{13}$

b. Dapat menyesuaikan diri

Penyesuaian diri (self adjustment) merupakan proses untuk memperoleh/ memenuhi kebutuhan (needs satisfaction), dan mengatasi stres, konflik, frustasi, serta masalah-masalah tertentu dengan cara-cara tertentu. Seseorang dapat dikatakan memiliki penyesuaian diri yang normal apabila dia mampu memenuhi kebutuhan dan mengatasi masalahnya secara wajar, tidak merugikan diri sendiri dan lingkungannya, serta sesuai denagn norma agama. ${ }^{14}$

c. Memanfaatkan potensi semaksimal mungkin

Individu yang sehat mentalnya adalah yang mampu memanfaatkan potensi yang dimilikinya, dalam kegiatan-kegiatan yang positif dan konstruktif bagi pengembangan kualitas dirinya. pemanfaatan itu seperti dalam kegiatankegiatan belajar (dirumah, sekolah atau dilingkungan masyarakat), bekerja, berorganisasi, pengembangan hobi, dan berolahraga. ${ }^{15}$

12 Zakiah Daradjat, Peranan Agama dalam Kesehatan Mental, Jakarta: Gunung Agung, 1978), h. 54

${ }^{13}$ Zakiah Daradjat, Peranan Agama dalam Kesehatan Mental, (Jakarta: Gunung Agung, 1978), h. 59

${ }^{14}$ Sururin, Ilmu Jiwa Agama, (Jakarta PT. Raja Grafindo Persada, 2004), h.113

15 Sururin, Ilmu Jiwa Agama, (Jakarta PT. Raja Grafindo Persada, 2004), h. 115 
d. Tercapai kebahagiaan pribadi dan orang lain

Orang yang sehat mentalnya menampilkan perilaku atau responresponnya terhadap situasi dalam memenuhi kebutuhannya, memberikan dampak yang positif bagi dirinya dan atau orang lain. dia mempunyai prinsip bahwa tidak mengorbankan hak orang lain demi kepentingan dirnya sendiri di atas kerugian orang lain. Segala aktivitasnya di tujukan untuk mencapai kebahagiaan bersama.

Karakteristik pribadi yang sehat mentalnya juga dijelaskan pada tabel sebagai berikut (Syamsu Yusuf LN ; 1987). ${ }^{16}$

\begin{tabular}{|c|c|}
\hline ASPEK PRIBADI & KARAKTERISTIK \\
\hline Fisik & $\begin{array}{l}\text { Perkembangannya normal. } \\
\text { Berfungsi untuk melakukan tugas-tugasnya. } \\
\text { Sehat, tidak sakit-sakitan. }\end{array}$ \\
\hline Psikis & $\begin{array}{l}\text { Respek terhadap diri sendiri dan orang lain. } \\
\text { Memiliki Insight dan rasa humor. } \\
\text { Memiliki respons emosional yang wajar. } \\
\text { Mampu berpikir realistik dan objektif. } \\
\text { Terhindar dari gangguan-gangguan psikologis. } \\
\text { Bersifat kreatif dan inovatif. } \\
\text { Bersifat terbuka dan fleksibel, tidak difensif. } \\
\text { Memiliki perasaan bebas untuk memilih, menyatakan pendapat dan } \\
\text { bertindak. }\end{array}$ \\
\hline Sosial & $\begin{array}{l}\text { Memiliki perasaan empati dan rasa kasih sayang (affection) terhadap } \\
\text { orang lain, serta senang untuk memberikan pertolongan kepada orang- } \\
\text { orang yang memerlukan pertolongan (sikap alturis). } \\
\text { Mampu berhubungan dengan orang lain secara sehat, penuh cinta } \\
\text { kasih dan persahabatan. } \\
\text { Bersifat toleran dan mau menerima tanpa memandang kelas sosial, } \\
\text { tingkat pendidikan, politik, agama, suku, ras, atau warna kulit. }\end{array}$ \\
\hline Moral-Religius & $\begin{array}{l}\text { Beriman kepada Allah, dan taat mengamalkan ajaran-Nya. } \\
\text { Jujur, amanah (bertanggung jawab), dan ikhlas dalam beramal. }\end{array}$ \\
\hline
\end{tabular}

Dari uraian di atas, menunjukan ciri-ciri mental yang sehat, dikelompokkan ke dalam enam kategori, yaitu:

a. Memiliki sikap batin (attitude) yang positif terhadap dirinya sendiri.

b. Aktualisasi diri.

c. Mampu mengadakan integrasi dengan fungsi-fungsi psikis yang ada.

d. Mampu ber-otonom terhadap diri sendiri (Mandiri).

e. Memiliki persepsi yang obyektif terhadap realitas yang ada.

f. Mampu menyelaraskan kondisi lingkungan dengan diri sendiri. ${ }^{17}$ 
Menurut Zakiah Darajat, orang yang sehat mentalnya memiliki sifat-sifat khusus, antara lain mempunyai kemampuan untuk bertindak secara efesien, memiliki hidup yang jelas, memiliki konsep hidup yang sehat, dan memiliki batin yang selalu tenang. ${ }^{18}$ Sedangkan Menurut Muhammad Mahmud terdapat 9 indikasi mental yang sehat, yaitu:

Pertama, kemapanan, ketenangan, dan rileks. Kata "sakinab" memiliki arti kemapanan disebabkan memiliki tempat tinggal atau wilayah yang menetap dan tidak berpindah-pindah. Ketenangan di dalam istilah sakinah tidak berarti statis atau tidak bergerak, sebab dalam "sakinah" terdapat aktivitas yang disertai dengan perasaan tenang, seperti orang yang melakukan kerja dengan disertai rasa tenang. Sedangkan rileks merupakan akibat dari sakinah dan thuma'ninah, yaitu keadaan batin yang santai, tenang, dan tanpa adanya tekanan emosi yang kuat, meskipun mengerjakan pekerjaan yang amat berat. Seseorang yang memiliki jiwa yang kotor dan penuh dosa karena maksiat, maka elemen-elemen yang jahat mudah bersenyawa dan membentuk komposisi tubuh yang gambang terkena goncangan, keresahan, dan kebimbangan. ${ }^{19}$

Kondisi mental yang tenang dan tentram dapat digambarkan dalam tiga bentuk yaitu ${ }^{20}$ :

a. Adanya kemampuan individu dalam menghadapi perubahan dan persoalan zaman. Misalnya jika ia terkena musibah maka musibah itu diserahkan dan dikembalikan kepada Allah (QS. Al-Baqarah : 156);

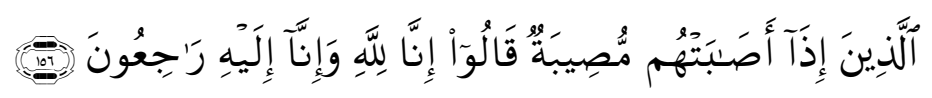

(yaitu) orang-orang yang apabila ditimpa musibah, mereka mengucapkan: "Inna lillaabi wa innaa ilaibi raaji'unn"

b. Kemampuan individu dalam bersabar mengahadapi persoalan-persoalan hidup yang berat, misalnya cobaan akan ketakutan dan kemiskinan (QS. Albaqarah : 155)

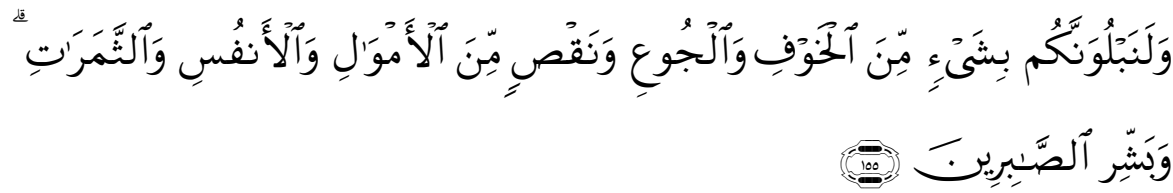

18 Zakiah Daradjat, Peranan Agama dalam Kesehatan Mental, Jakarta: Gunung Agung, 1978), h. 62

${ }^{19}$ Muhammad Mahmud, 'Ilm al-Nafs al-Ma'ashir fi Dhaw 'T al-Islam, Jeddah: Dar al-Syuruq, 1984), h. 301

${ }^{20}$ Syamsu Yusuf. 2009. Mental Hygiene, (Bandung : Maestro, 2003), h. 117 
dan sungguh akan Kami berikan cobaan kepadamu, dengan sedikit ketakutan, kelaparan, kekurangan harta, jiwna dan buah-buahan. dan berikanlah berita gembira kepada orangorang yang sabar.

c. Kemampuan individu untuk optimis dan menganggap baik dalam menempuh kehidupan, sebab setiap ada kesulitan pasti akan dating kemudahan (QS. Al-insyirah: 4-5).

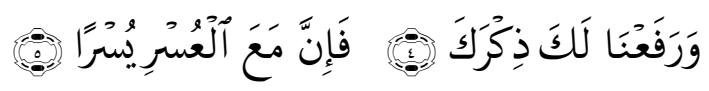

Dan Kami tinggikan bagimu sebutan (nama)mu, karena Sesunggubnya sesudah kesulitan itu ada kemudahan,

Kedua, memadahi dalam beraktivitas. Seseorang yang mengenal potensi, keterampilan dan kedudukannya secara baik maka ia dapat bekerja dengan baik pula, dan hal itu merupakan tanda dari kesehatan mentalnya. Firman Allah SWT:

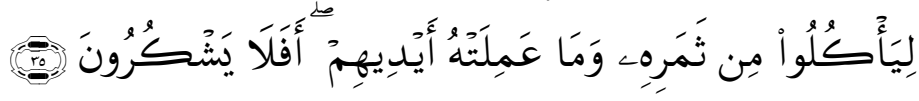

"Supaya mereka dapat makan dari buahnya, dan dari apa yang diusahakan oleh tangan mereka. Maka mengapakah mereka tidak bersyukur?” (QS.Yasin: 35).

Sabda Nabi SAW : "Makanan yang lebih baik dimakan oleh seseorang adalah makanan yang berasal dari jerih payahnya sendiri, sebab Nabi Dawnd makan dari hasil kerjanya sendiri." (HR.Al-Bukhari)

Ketiga, menerima keberadaan dirinya dan keberadaan orang lain. Orang yang sehat mentalnya adalah orang yang menerima keadaan sendiri, baik berkaitan dengan kondisi fisik, kedudukan, potensi, maupun kemampuannya, karena keadaan itu merupakan anugrah dari Allah SWT. Anugrah Tuhan yang diberikan kepada manusia terdapat dua jenis, yaitu: (1) bersifat alami. Manusia yang sehat akan mensyukuri anugrah itu tanpa mempertanyakan mengapa Tuhan menciptakan seperti itu, sebab di balik penciptaan-Nya pasti terdapat hikmah yang tersembunyi; (2) dapat diusahakan. Manusia yang sehat tentunya akan mengerahkan segala daya upayanya secara optimal agar dapat mencapai tujuan yang diinginkan. Tanda kesehata mental yang lain adalah adanya kesediaan diri untuk menerima segala kelebihan dan kekurangan orang lain, sehingga ia mampu bergaul dan menyesuaikan diri dengan orang lain.

Keempat, adanya kemampuan untuk memelihara atau menjaga diri. Artinya, kesehatan mental seseorang ditandai dengan kemampuan untuk memilah-milah dan mempertimbangkan perbuatan yang akan dilakukan. Perbuatan yang hina dapat menyebabkan psikopatologi, sedang perbuatan yang baik menyebabkan pemeliharaan kesehatan mental. Kelima, kemampuan untuk memikul tanggung jawab, baik tanggung jawab keluarga, sosial, maupun agama. 
Keenam, memiliki kemampuan untuk berkorban dan menebus kesalahan yang diperbuat. Ketujuh, kemampuan individu untuk membentuk hubungan sosial yang baik yang dilandasi sikap saling percaya dan saling mengisi. Kedelapan, memiliki keinginan yang realistik, sehingga dapat diraih secara baik. Kesembilan, adanya rasa kepuasan, kegembiraan dan kebahagiaan dalam mensikapi atau menerima nikmat yang diperoleh. ${ }^{21}$

\section{Ciri-ciri penyakit mental menurut Islam}

Ada beberapa ciri mental yang sakit menurut Islam, yaitu :

a. Bertingkah laku karena motif ingin dipuji atau diperhatikan orang lain. (Qs. An-Nisa:142, Qs. At-Taubah:67)

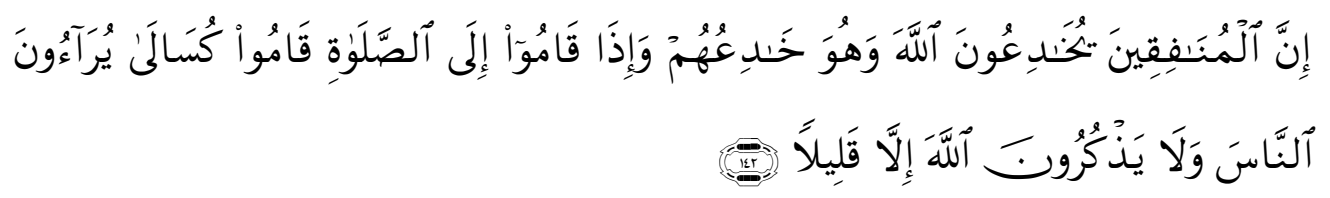

"Sesunggubnya orang-orang munafike itu menipu Allah, dan Allah akan membalas tipuan mereka dan apabila mereka berdiri untuk shalat mereka berdiri dengan malas. mereka bermaksud riya (dengan shalat) di hadapan manusia. dan tidaklah mereka menyebut Allah kecuali sedikit sekali."

b. Hasad dan dengki atau iri hati yaitu tidak suka pada kebahagiaan orang lain. (Qs. An-Nisa: 54)

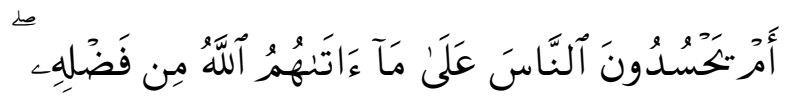

Ataukah mereka dengki kepada manusia (Mubammad) lantaran karunia yang Allah telah berikan kepadanya?

(Qs.Al Falaq 1-5)

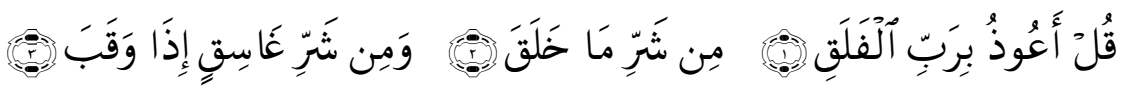

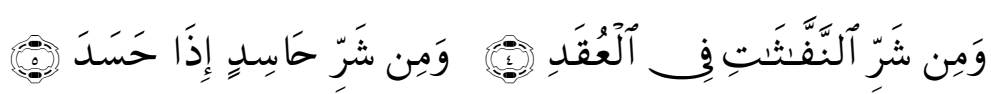

Katakanlab: "Aku berlindung kepada Tuhan yang menguasai subuh, Dari kejahatan makbluk-Nya, Dan dari kejahatan malam apabila telah gelap gulita, Dan dari kejabatan wanita-wanita tukang sibir yang menghembus pada bubul-bubul. Dan dari kejabatan pendengki bila ia dengki."

c. Rakus yaitu hasrat yang berlebih-lebihan dalam makan.

d. Waswas. Para pemikir islam berpendapat bahwa waswas merupakan bisikan hati, akan cita-cita dan angan-angannya dalam nafsu dan kelezatan.

${ }^{21}$ Muhammad Mahmud, 'Ilm al-Nafs al-Ma'ashir fi Dhaw I al-Islam, (Jeddah: Dar al-Syuruq, 1984), h. 320 
e. Bicara berlebih-lebihan. Jika seseorang menyukai bicara yang berlebihan maka dia akan lebih banyak berbohong.

f. Melaknati orang yaitu menyumpahi atau mendoakan hal-hal yang buruk untuk orang lain.

g. Ingkar janji. Jika janji itu diingkari karena nafsu bukan karena hal-hal yang mendesak.

h. Berbohong.

i. Mengadukan orang lain (naminah) yaitu menyampaikan hal-hal yang tidak disukai oleh orang yang bersangkutan.

j. Membicarakan kejelekan orang lain di belakang orang tersebut (gbibah).

k. Sangat marah (syiddah alghadab).

1. Cinta dunia (bubb ad dunya).

m. Cinta harta (bub al-mal).

n. Kebakhilan yaitu pelit atau menyembunyikan dan menumpuk harta.

o. Cinta pada kedudukan atau pangkat (bubb al-jab).

p. Kesombongan (kibr) atau bangga (ujub). ${ }^{22}$

Dari uraian di atas dapat disimpulkan bahwa secara umum penyakit mental dalam Islam ada 17 bentuk, yaitu ; selalu ingin dipuji, hasad dan dengki, rakus, was-was, bebicara berlebih-lebihan, melaknati dan menyumpahi orang lain,inkar janji, bebohong, suka adu domba, suka membicarakan kejelekan orang lain, pemarah, terlalu mencintai dunia,telalu mencintai harta, bakhil, telalu mencintai pangkat, dan sombong.

\section{Metode Perawatan Kesehatan Mental Dalam Islam}

Dalam Islam, Ada tiga pola yang dikembangkan untuk mengungkap metode perolehan dan pemeliharaan kesehatan mental: Pertama, metode tahalli, takhalli, dan tajalli; Kedua, metode syariah, thariqah, haqiqah, dan ma'rifat; dan ketiga, metode iman, islam, dan ihsan. Di sini, kita lebih cenderung memilih pola yang ketiga. ${ }^{23}$

\section{a. Metode Imaniyah}

Iman secara harfiah diartikan dengan rasa aman (al-aman) dan kepercayaan (al-amanah). Orang yang beriman berarti jiwanya merasa tenang dan sikapnya penuh keyakinan dalam menghadapi problem hidup. Dengan iman, seseorang memiliki tempat bergantung, tempat mengadu, dan tempat memohon apabila ia ditimpa problema atau kesulitan hidup, baik yang berkaitan dengan perilaku fisik maupun psikis. Ketika seseorang telah mengerahkan daya upayanya secara maksimal untuk mencapai satu tujuan, namun tetap mengalami kegagalan, tidak berarti kemudian ia putus asa atau malah bunuh diri.

\footnotetext{
22 Yusak Burhanuddin. Kesehatan Mental, (Bandung: Pustaka Setia, 1998), h.70
}

${ }^{23}$ Yusak Burhanuddin. Kesehatan Mental, (Bandung: Pustaka Setia, 1998), h. 74 


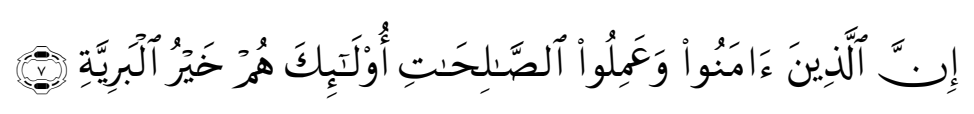

Sesunggubnya orang-orang yang beriman dan mengerjakan amal saleh, mereka itu adalah Sebaik-baik makbluk.

Keimanan akan mengarahkan seseorang untuk mengoreksi diri apakah usahanya sudah maksimal atau belum. Sejalan dengan hukum-hukum-Nya atau tidak. Jika sesuai dengan hukum-hukum-Nya, tetapi masih menemu ikegagalan, hal yang perlu diperhatikan adalah hikmah dibalik kegagalan tersebut. Apakah Allah SWT menguji kualitas keimanannya melalui kegagalan ataukah Dia mengasihi hamba-Nya yang salih supaya ia tidak sombong atau angkuh ketika memperoleh kesuksesan. Keimanan mempunyai pengaruh yang besar terhadap manusia. Pengaruh itu terutama membuat manusia percaya pada diri sendiri, meningkatkan kemampuannya untuk sazbar dan kuat menanggung derita kehidupan, membangkitkan rasa tenang dan tenteram dalam jiwa, menimbulkan kedamaian hati dan memberi perasaan bahagia.

Keimanan kepada Allah dibarengi dan diikuti oleh ketaqwaan kepadaNya. Pengertian taqwa dalam bahasan Al-Qur'an banyak, di antaanya takut(yang berarti takut melanggar ketentuan Allah), menjaga atau membentengi diri dari berbagai dorongan yang tercela dan perbuatan mungkar, menjaga diri dari tingkah laku yang tidak terpuji. Keimanan yang direalisasikan secara benar akan membentuk kepribadian mukmin yang membentuk enam karakter:

1) Karakter Rabbani, yaitu karakter yang mampu mentransinternalisasikan( mangambil dan mengamalkan) sifat-sifat dan asma-asma allah SWT ke dalam tingkah laku nyata sebatas pada kemampuan manusiawinya.

Proses pembentukan karakter rabbani dapat ditempuh melalui tiga tahap, yaitu ta'alluq, takhalluq dan tahaqquq. Proses ta'alluq adalah menggantungkan kesadaran diri dan pikian kepada Allah dengan cara berpikir dan berzikir kepada-Nya. Sebagaiman Fiman Allah dalam QS Ali Iman ayat 191:

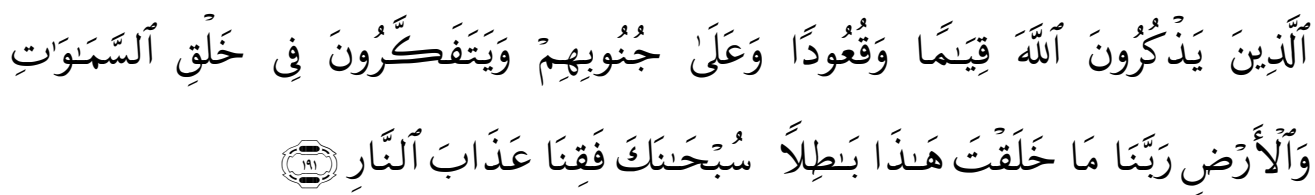

(yaitu) orang-orang yang mengingat Allah sambil berdiri atau duduk atau dalam keadan berbaring dan mereka memikirkan tentang penciptaan langit dan bumi (seraya berkata): "Ya Tuban Kami, Tiadalah Engkau menciptakan ini dengan sia-sia, Maha suci Engkau, Maka peliharalah Kami dari siksa neraka.

Proses takhalluq adalah adanya kesadaran diri untuk mentransinternalisasikan sifat-sifat dan asma-asma Allah SWT sebatas pada kemampuan manusiawinya. Proses ini dilakukan sebab fitrah manusia memilki potensi Asma 'al husna. Proses tahaqquq adalah kesadaan diri akan adanya 
kebenaran, kemuliaan, keagungan Allah SW'T, sehingga tingkah lakunya didominasi oleh-Nya.

2) Karakter Malaki, yaitu karakter yang mampu mentransinternalisasikan sifatsifat malaikat yang agung dan muliah. Karakter kepribadian malaki di antaranya adalah:

3) Karakter Qur-ani, yaitu mampu mentransinternalisasikan nilai-nilai al-quran dalam tingkah laku nyata. Karakter kepribadian qurani di antaranya adalah membaca, memahami, dan mengamalkan ajaran yang terkandung di dalam al-Quran dan Sunnah, sebab ia memberikan petunjuk (al-hidayah), rahmah (al-rahmah), berita gembira (al-tabsyir) bagi orang muslim yang bertaqwa (QS. Al-Nahl:2) serta memberikan wawasan yang totalitas untuk semua aspek kehidupan (QS. Al- An'am:38).

4) Karakter Rasuli, yaitu karakter yang mampu mentransinternalisasikan sifatsifat rasul yang mulia. Karakter kepribadian rasuli di antaranya adalah jujur (al-shiddiq), dapat dipercaya( al-amanah), menyampaikan informasi atau wahyu (al-tabligh), dan cerdas (al-fathonah).

5) Karakter yang berwawasan dan mementingkan masa depan (hari akhir), karakter ini menghendaki adanya karakter yang mementingkan jangka panjang daripada jangka pendek atau wawasan masa depan daripada masa kini(QS. Al-Duha:4), memiliki sikap tanggung jawab, melakukan sholat, zakat, dan selalu bertaqwa( QS. Al-nisa': 77), tingkah lakunya penuh perhitungan sebab nanti semuanya diperhitungkan (hisab).

6) Karakter Takdiri, yaitu karakter yang menghendaki adanya penyerahan dan kepatuhan pada hukum-hukum, aturan-aturan, dan sunnah-sunnah Allah SWT. Karakter ini di antaranya adalah mengetahui dan mematuhi sunnahsunnah Allah SWT., baik sunnah qurani amaupun sunnah kauni. ${ }^{24}$

\section{b. Metode Islamiah}

Islam secara etimologi memiliki tiga makna, yaitu penyerahan dan ketundukan (al-silm), perdamaian dan keamanan (al-salm), dan keselamatan (alsalamab). Realisasi metode Islam dapat membentuk kepribadian muslim (syakbshiyah al-muslim) yang mendorong seseorang untuk hidup bersih, suci dan dapat menyesuaikan diri dalam setiap kondisi. Kondisi seperti itu merupakan syarat mutlak bagi terciptanya kesehatan mental. Kepribadian muslim menimbulkan lima karakter ideal yaitu:

1) Karakter syahadatain yaitu karakter yang mampu menghilangkan dan membebaskan diri dari segala belenggu dan dominasi tuhan-tuhan temporal dan relatif, seperti materi dan hawa nafsu.

${ }^{24}$ Abdul Mujib \& Mudzakir, Jusuf, Nuansa-Nuansa Psikologi Islam, (Jakarta: PT Raja Grafind Persada, 2001), h. 227 
2) Karakter mushalli, yaitu karakter yang mampu berkomunikasi dengan Allah (ilahi) dan dengan sesama manusia (insani). Komunikasi ilahiah ditandai dengan takbir, sedang komunikasi insaniah ditandai dengan salam. Karakter mushalli juga menghendaki kesucian lahir dan batin. Kesucian lahir diwujudkan dalam wudhu (Q.S. Al-Maidah:6), sedang kesucian batin diwujudkan dalam bentuk keikhlasan dan kekhusyukan (Q.S. al-Mukminun: $1-2)$.

Ia juga menghendaki adanya konsentrasi penuh tanpa diganggu oleh dominasi minuman keras, narkoba atau zat adiktif lainnya.

3) karakter muzakki, yaitu karakter yang berani mengorbankan hartanya untuk kebersihan dan kesucian jiwanya (Q.S. At-Taubah: 103). Karakter Muzakki menghendaki adanya pencarian harta secara halal dan mendistribusikannya dengan cara yang halal pula. Ia menuntut adanya produktifitas dan kreativitas.

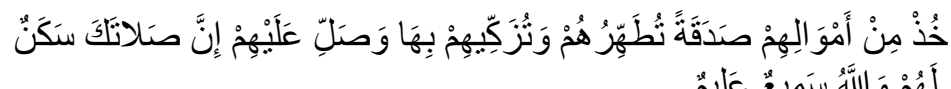

Artinya : Ambillah qakat dari sebagian harta mereka, dengan zakat itu kamu membersibkan dan mensucikan mereka dan mendoalah untuk mereka. Sesunggubnya doa kamu itu (menjadi) ketenteraman jïwa bagi mereka. dan Allah Maha mendengar lagi Maha mengetahui.

4) Karakter sha'im, yaitu karakter yang mampu mengendalikan dan menahan nafsu-nafsu rendah dan liar. Di antara karakter sha'im adalah menahan makan, minum, hubungan seksual pada waktu, dan tempat dilarang.

5) Karakter hajji, yaitu karakter yang mau mengorbankan harta, waktu, bahkan nyawa demi memenuhi panggilan Allah SWT. Karakter ini menghasilkan jiwa yang egaliter, memiliki wawasan inklusif dan pluralistik, melawan kebatilan, serta meningkatkan wawasan wisata spiritual. ${ }^{25}$

\section{c. Metode Ihsaniah}

Ihsan secara bahasa berarti baik. Orang yang baik (muhsin) adalah orang yang mengetahui akan hal-hal baik, mengaplikasikan dengan prosedur yang baik, dan dilakukan dengan niatan baik pula. Metode ini apabila dilakukan dengan benar akan membentuk kepribadian muhsin (syakbshiyah al-mubsin) yang dapat ditempuh melalui beberapa tahapan.

1) Tahapan permulaan (al-bidayab). Tahapan ini disebut juga tahapan takhalli. Takhalli adalah mengosongkan diri dari segala sifat-sifat kotor, tercela, dan maksiat.

25 Abdul Mujib \& Mudzakir, Jusuf, Nuansa-Nuansa Psikologi Islam, Jakarta: PT Raja Grafind Persada, 2001), h. 229 
2) Tahapan kesungguhan dalam menempuh kebaikan (al-mujahadat). Pada tahapan ini kepribadian seseorang telah bersih dari sifat-sifat tercela dan maksiat, kemudian ia berusaha dengan sungguh-sungguh untuk mengisi diri dengan tingkah laku yang baik. Tahapan ini disebut juga tahalli. Tahalli adalah upaya mengisi diri dengan sifat-sifat yang baik. Tahapan ini harus ditopang oleh tujuh pendidikan dan latihan psiko pisik. Tujuh pendidikan itu adalah :

a) Musyarathah, yaitu memberikan dan menentukan syarat bagi diri sendiri, melalui cara: membekali diri dengan iman dan Ilmu pengetahuan; memperingati diri menjauhi segala ma'siat dan mendekati perbuatan ma'ruf.

b) Muraqabah, yaitu mawas diri dari perbuatan ma'siat agar selalu dekat kepada Allah. Kedekatan Allah dengan manusia sangat tergantung pada kedekatan manusia. Jika manusia mendekat niscaya Allah mendekat, tetapi jika manusia menjauh niscaya Allah menjauh. Jika manusia mendekat selangkah, maka Allah mendekat dua, tiga, atau tak terhingga kedekatan-Nya dengan manusia. Namun jika manusia menjauh selangkah, maka Allah tidak menjauh melebihi manusia. Allah Maha Adil Yang tidak pernah menzalimi hamba-Nya, bahkan sifat Rahman, RahimNya lebih dahulu dan lebih dekat dari pada sifat Ghadhaf(marah)-Nya.

c) Muhasabah, yaitu membuat perhitungan tehadap tingkah laku yang diperbuat. Apakah perbuatan yang dilakukan hari ini lebih bazik dari harihari kemarin.Jika lebih jelek maka ia harus beristighfar dan berusaha memperbaikinya. Jika sama berarti kehidupannya statis dan tidak memperoleh nilai lebih sama sekali.Jika ternyata lebih baik maka harus disyukuri dan tetap dilakukan secara istiqamah.

d) Mu'aqabah, yaitu menghukum diri karena melakukan keburukan. Cara menghukum diri tidak seperti umat-umat terdahulu dengan cara bunuh diri, baik secara personal maupun massal, melainkan dengan cara berbuat baik, sebab perbuatan baik dapat menghapus perbauatan buruk.

e) Mujahadah, yaitu bersungguh-sungguh berusaha menjadi baik. Dalam kesungguhan itu, seseorang tidak lagi memperdulikan pengorbanan yang dikeluarkan, baik dengan harta maupun jiwa. Dalam mujahadah diperlukan adanya jihad dan ijtihad, sedangkan jihad yang paling berat adalah melawan hawa nafsu.

f) Mu'atabah, yaitu menyesali diri atas perbuatan dosanya. Cara penyesalan itu dengan bertaubat, yaitu kembali pada hukum-hukum dan aturanaturan Allah. Manusia yang baik tidak berarti manusia yang tidak pernah melakukan dosa, tetapi manusia yang baik adalah manusia yang apabila melakukan dosa dan ma'siat ia segera menyadarinya dan berusaha untuk tidak mengulangi lagi dengan sekuat tenaga.

g) Mukasyafah, yaitu membuka penghalang atau tabir agar tersingkap semua rahasia Allah. Pada level ini, tabir (Hijab) yang menghalangi antara 
manusia dan rahasia Tuhan mulai hilang dan tersingkap, sehingga seseorang mengetahui hukum-hukum dan rahasia Tuhan secara haqq alYaqin. Ketika seseorang telah memperoleh Kasyaf maka pola hidupnya selalu baik dan benar terhindar dari hal-hal yang mungkar, dan dapat mengantarkan kebahagiaan hidup di dunia dan di akhirat. Ketidak bahagiaan seseorang sesungguhnya disebabkan oleh ketidak tahuannya cara dan hukum yang ditempuh untuk memperoleh kebahagiaan itu. ${ }^{26}$

3) Tahapan merasakan (al-muriqat).

Pada tahapan ini, seorang hamba tidak sekadar menjalankan perintah Khaliknya dan menjauhi larangan-Nya, namun ia merasa kelezatan, kedekatan, kerinduan, dengan-Nya. Tahapan ini disebut Tajalli. Tajalli buruknya dihilangkan dan tabir yang menghalangi menjadi sirna.

Tahapan ketiga ini bagi para sufi baiasanya didahului oleh dua proses, yaitu al-Fana dan Al-Baqa. Seseorang apabila mampu menghilangkan wujud jasmania dengan cara menghilangkan nafsu-nafsu inklusifnya dan tidak teikat oleh materi atau lingkungan sekitar, maka ketika ini ia telah Al-Fana. Kondisi itu kemudia bealih kepada Kebaqaan wanjud Rubaniyah yang ditandai dengan tetapnya sifat-sifat ketuhanan.

Ketika tahapan tersebut telah dilalui maka muncullah apa yang disebut dengan al-Hal, yaitu kondisi spiritual yang mana sang pribadi telah mencapai kebahagiaan tertinggi yang dicita-citakannya. Kondisi ini merupakan karunia dan rahmat dari Allah dan tidak dapat diusahakan sewaktu-waktu. Ia datang secara tiba-tiba dan hilang secara tiba-tiba pula. Sesaat dalam al-Hal dapat dirasakan dan dinikmati oleh sang pribadi selama betahun-tahun, sebab al-Hal telah memasuki dimensi Ilahiyah yang ukurannya tidak terbatas oleh ruang dan waktu.

\section{Penutup}

Hubungan agama dengan kesehatan mental dalam Islam adalah sebagai terapi, yaitu terletak pada sikap penyerahan diri seutuhnya kepada Allah SWT, dengan penyerahan sepenuhnya maka ketenangan jiwa akan di dapati, yang nantinya dapat membentuk hidup manusia jadi seimbang dunia akhirat. Ada tiga pola yang dikembangkan untuk mengungkap metode perolehan dan pemeliharaan kesehatan mental dalam Islam: Pertama, metode tahalli, takhalli, dan tajalli; Kedua, metode syariah, thariqah, haqiqah, dan ma'rifat; dan Ketiga, metode iman, islam, dan ihsan. Di sini, kita lebih cenderung memilih pola yang ketiga.

${ }^{26}$ Abdul Mujib \& Mudzakir, Jusuf, Nuansa-Nuansa Psikologi Islam, (Jakarta: PT Raja Grafind Persada, 2001), h. 239 
90 | ISLAMIC COUNSELING: Jurnal Bimbingan dan Konseling Islam, vol. 3, no. 1, 2019

\section{Bibliografi}

Muhammad Mahmud Mahmud, 'Ilm al-Nafs al-Ma'ashir fi Dhaw I al-Islam, Jeddah: Dar al-Syuruq, 1984

Mujib, Abdul \& Mudzakir, Jusuf. 2001. Nuansa-Nuansa Psikologi Islam. Jakarta: PT Raja Grafind Persada

Zakiah Daradjat, Kesehatan Mental, LP IAIN, Jakarta, 1985

Hanna Djumhana Bustaman, Integrasi Psikologi dengan Islam, Pustaka Pelajar, Yogyakarta

Jalaluddin, Psikologi Agama, Jakarta: PT Raja Grafindo Persada, 2010

Zakiah Daradjat, Peranan Agama dalam Kesehatan Mental, (Jakarta: Gunung Agung, 1978

Syamsu Yusuf. 2009. Mental Hygiene. Bandung : Maestro

Yusak Burhanuddin. Kesehatan Mental, Bandung: Pustaka Setia, 1998

Sururin, Ilmu Jiwa Agama, Jakarta PT. Raja Grafindo Persada, 2004

Nasruddin Razak, Dinul Islam. Penafsiran kembali Islam sebagai suatu "Aqidab dan Way Of Life 'T, Bandung, Al-Ma'arif, 1977 